\title{
Human Rights, Emerging Markets, and International Business a
}

Florian Wettstein

The Oxford Handbook of Management in Emerging Markets

Edited by Robert Grosse and Klaus E. Meyer

Print Publication Date: Mar 2019 Subject: Business and Management, International Business Online Publication Date: Aug 2018 DOI: 10.1093/oxfordhb/9780190683948.013.39

\section{Abstract and Keywords}

This chapter provides an introduction to business and human rights (BHR) as a new research field in the intersection of corporate responsibility and international business and specifically reflects on it through, and relates it to, an emerging economies perspective. It aims at outlining the basic contours of the BHR field, clarifying its underlying rationale, as well as providing an overview of some prevalent issues and delineating it from other related concepts such as, particularly, corporate social responsibility. The chapter concludes with a reflection on some key research trends and themes emerging from the BHR field, which may be of particular relevance to international business and emerging markets scholars.

Keywords: human rights, corporate social responsibility, international business, multinational corporations, emerging economies

CORPORATIONS and human rights have not traditionally been theorized in tandem. Not even the well-established discussion on corporate social responsibility (CSR), which emerged as early as the 1950s and 1960s (Bowen, 1953; Davis, 1960; Frederick, 1960; Votaw, 1961), has given much thought to the relation between companies and human rights (Wettstein, 2012a). Human rights were-and partly still are today-perceived as applying exclusively to governments; corporations, on the other hand, were not perceived to have any direct human rights obligations (Muchlinski 2001). At best, such was, and partly still is, the view that corporations can have indirect human rights obligations, insofar as national governments ask them to comply with certain human rights requirements through domestic laws and regulations. Such obligations, however, are then understood as a part of a corporation's legal compliance rather than of its extra-legal social responsibility.

Challenges to this perception emerged in the 1970s, but they started to gain real traction throughout the 1990s, in the wake of Western companies operating in and partly bolstering the South African apartheid regime, and later against the background of emerging sweatshop practices or the lasting detrimental impact of oil companies in the Niger Delta. 


\section{Human Rights, Emerging Markets, and International Business}

A series of critical reports of prominent human rights organizations triggered a more systematic discussion on the responsibilities of business vis-à-vis human rights in the late 1990s (see, e.g., Human Rights Watch, 1999a, 1999b). Twenty years in, what is now called the "business and human rights debate" (Chandler, 2003) has turned into one of the most influential drivers within the larger discussion on corporate responsibility.

In this chapter, I trace the evolution of this fast-paced and increasingly prominent debate, specifically as it pertains to and is relevant for the context of emerging economies. The goal and ambition of this chapter is to provide a (reasonably) comprehensive (p. 374) overview-and introduction-to this emerging discussion, specifically for international business (IB) scholars with an interest in emerging markets. Furthermore, it shall outline the relevance of business and human rights (BHR) for the field of study of IB and emerging market scholars, as well as research needs and opportunities at the intersection of BHR and emerging markets scholarship.

The chapter proceeds as follows: after this brief introduction, section two outlines the basic shape and rationale of the BHR debate. It starts with the most fundamental question why corporations ought to have human rights responsibility to begin with. To answer this question, I distinguish legal, moral, and political accounts of BHR and briefly outline some of the main strands of argumentation found within these approaches. Section three delineates the BHR debate from the more established CSR discussion. Despite the close connection between the two fields, they have evolved largely in parallel (Wettstein, 2012a) and it is critical for a proper understanding of the developments in today's BHR space to take note of both the similarities and the conceptual differences between these two discussions. I analyze the relation between CSR and BHR in three dimensions: normative, institutional, and operational. Section four briefly maps the institutional landscape in the BHR space at the international level. I specifically emphasize UN-driven initiatives. In section 5, readers can take a closer look at the UN Guiding Principles (UNGPs) on business and human rights. The UNGPs are the authoritative global policy instrument today and the "focal point" (Ruggie, 2011: 3) on which the BHR debate centers. The section discusses the content and structure of the UNGPs, but also emerging new instruments particularly at the domestic level, to which the implementation of the UNGPs have given rise. Outlining developments in the policy, legislative, and adjudicative space, the section traces a clear international trend for binding human rights regulation, which is, however, modeled after the soft-law provisions stipulated in the UNGPs. More generally, the mapping of the institutional landscape in sections four and five paints a picture of a complex interplay between binding and non-binding governance approaches in the BHR space. Section six outlines some of the key themes and open research needs deriving from the current scholarly discussion on BHR against the background of this evolving institutional infrastructure. The section is structured into research themes at the global, state, and operational level. Section seven maintains a focus on research themes with specific emphasis on the intersection between BHR and the context of emerging economies research. The eighth and final section concludes. 


\section{Why Corporate Human Rights Responsibility}

As outlined in the introduction, corporations have not traditionally been perceived as having human rights responsibilities. Rather, such responsibility was assigned exclusively to governments (Muchlinski, 2001). This state centrism underlying traditional (p. 375) human rights thinking is rooted most prevalently in legal scholarship and practice, but it is common also in political and ethical thinking on human rights (Wettstein, 2009: 156-164). It is one reason why, as we will see, the established debate on CSR has been reluctant to engage with human rights in a systematic manner until very recently. However, the accelerating globalization of markets and the rise of multinational business in the 1970s and particularly throughout what Joseph Stiglitz (2003) called the "roaring nineties" increasingly put this state-centric approach to human rights to the test (Kobrin, 2009). The expansion of global markets and multinational value chains meant that multinational companies increasingly operated in contexts of weak institutions, of governments unable or unwilling to protect the rights of its citizens or of abusive and authoritarian regimes actively engaged in their violation. Thus, there was a growing mismatch between the global expansion of economic forces and inadequate, spatially and territorially limited human rights protection (Wettstein, 2009). This raised new issues of collusion between multinationals and authoritarian governments in the oppression and violation of rights (Muchlinski, 2001; White, 2004), of exploitation of cheap labor in form of sweatshops and child labor (Arnold, 2003), or of forced dislocation of indigenous communities, among other things. With home state governments increasingly incapacitated to effectively regulate and fully control the multinational operations of "their" corporations, the focus started to shift on those corporations themselves as a locus of human rights responsibility. Such "governance gaps," as John Ruggie famously stated later on, turned into the "root cause of the business and human rights predicament" (2008: 3) that attracted increasing attention by NGOs (non-governmental organizations), international policymakers, and academics in the mid-1990s and onward.

However, as we know at least since David Hume (1985 [1740]), "is" does not imply "ought"; thus the de facto existence of governance gaps in and of itself can hardly ground corporate human rights obligations-a normative argument is needed in addition to the context raising the issue as a policy concern. Keeping this discussion brief for the sake of this chapter, three broad approaches to clarifying the underlying normative grounds for corporate human rights responsibility can be distinguished. I call them legal, moral, and political approaches.

\section{Legal Approaches}

Legal approaches to business and human rights have dominated the discussion since its very beginning (Wettstein, 2012a). Thus, such approaches look for the normative justification of corporate human rights responsibility in international or domestic law. Early approaches, for example, argued that both the Universal Declaration of Human Rights as well as the two International Covenants offer room for interpretation when it comes to the inclusion or exclusion of corporations as potential duty bearers (see, e.g., Frey, 1997).

Page 3 of 27

PRINTED FROM OXFORD HANDBOOKS ONLINE (www.oxfordhandbooks.com). (C) Oxford University Press, 2018. All Rights Reserved. Under the terms of the licence agreement, an individual user may print out a PDF of a single chapter of a title in Oxford Handbooks Online for personal use (for details see Privacy Policy and Legal Notice). 


\section{Human Rights, Emerging Markets, and International Business}

In addition, as John Ruggie points out, where corporations are involved in most egregious human rights violations such as, for example, genocide, war crimes and some crimes against humanity, "customary international law standards may apply directly to (p. 376) corporate entities under certain circumstances" (2013: 39). However, the enforcement of such responsibilities would have to occur in domestic courts in jurisdictions that allow for it. A related discussion deals with the status of multinational corporations under international law, that is, with the question of whether or not multinational companies possess international legal personality, which is a condition to be a subject and thus obligationbearer of international law (see, e.g., Muchlinski, 2001). Others have argued that the undisputed legal obligation of states to protect human rights against corporate abuse implies, by matter of contradiction, a similar obligation of business to respect human rights (Bilchitz, 2013). More recent approaches have focused on domestic law in addition to international law. Rather than deriving corporate human rights obligations directly from international law, they are interested in whether or not, or to what extent, international law implies a duty for governments to regulate and adjudicate multinational corporations' business conduct abroad (Simons \& Macklin, 2014). That is, they analyze the extraterritorial obligations of home states in regard to the business conduct of "their multinational companies" in host countries. Finally, instead of reinterpreting existing international law, there has been a growing discussion on the need and justification for a new international legal regime that deals specifically with corporate human rights obligations. Most prominently, this strand of research includes discussions on the need and nature of a binding international treaty on business and human rights (see, e.g., Bilchitz, 2016; De Schutter, 2016; Deva \& Bilchitz, 2017), as well as on the possibility to expand the jurisdiction of international human rights courts to corporate conduct (see, e.g., Scheinin 2012).

\section{Moral Approaches}

Business ethicists in particular have been searching for the moral grounds of corporate human rights responsibility (see Brenkert, 2016, for an overview). Rather than corporations' (international) legal personality, the foundation of corporate human rights responsibility from a moral perspective is their moral agency (see Arnold, 2016; Werhane, 2016, in regard to corporate human rights responsibility, and Donaldson, 1982, more generally). Based on the moral agency of corporations we can distinguish between limited and expansive accounts of corporate (moral) human rights responsibility. Limited accounts hold that corporations' human rights responsibilities are limited to duties of nonviolation (see, e.g., Arnold, 2010). Hsieh even argues that such limited duties must be derived from different moral grounds and thus do not amount to corporate human rights responsibilities in a more narrow sense (see Hsieh, 2015, 2017). Expansive accounts, on the other hand, argue that corporate human rights responsibilities entail not only negative responsibilities of non-violation but also positive ones to protect and realize human rights (see, e.g., Santoro, 2000, 2009; Wettstein, 2009, 2012a; Wood, 2012). In other words, such expansive accounts see a role for corporations also in the advancement and realization of human rights and in providing (p. 377) and contributing to solutions for some of the pressing human rights problems we are facing today. 


\section{Political Approaches}

Political approaches do not refer to international law or to ethical norms and principles to ground corporate human rights responsibility, but, rather, to political processes and social expectations. Most prominent among such approaches is John Ruggie's UN Respect, Protect and Remedy Framework and its operationalization by the UNGPs. Ruggie makes it clear that the UNGPs are not meant to ground and give rise to any new legal duties for businesses. Similarly, he abstains from providing a foundation grounded in moral normativity (Bilchitz, 2013). Instead, Ruggie derives the corporate responsibility to respect human rights from the changing social expectations toward companies as well as their instrumental interest not to fall out of favor of their key stakeholders and thus to maintain their social license to operate. The yardstick for corporate legitimacy in regard to its human rights conduct, according to Ruggie, are the "courts of public opinion" (2008: 16), which makes corporate human rights responsibility essentially a political responsibility. Not surprisingly, Ruggie was criticized both by legal scholars as well as by ethicists for neglecting the legal and moral dimensions of corporate human rights responsibility. Others proposed political accounts of corporate human rights responsibility are rooted in the publicness of corporations (Karp, 2014) or in their political power that needs to be balanced with public responsibility (Kobrin, 2009).

In sum, while the grounds on which to argue for corporate human rights responsibility vary widely, there is a strong and growing interdisciplinary case to be made that corporations indeed do have such a responsibility. However, how far such responsibilities reach and what they entail are subject to ongoing discussion.

\section{BHR as a CSR Issue?}

There is a danger that this newly evolving BHR debate may be seen as a mere subset of the broader and long-established CSR field or even only as a "CSR issue." However, while the two discussions-BHR and CSR-share significant overlaps in terms of the issues they cover as well as in their overarching objective to promote and advance responsible business practices beyond and, in part, in opposition to the profit- and shareholder value maximization mantra that has dominated management theory and practice for the last three or four decades, they do emanate from distinctly different starting points. Accordingly, the two discussions have followed separate and largely parallel paths and, as some scholars argue (Ramasastry, 2015; Wettstein, 2016) are currently in a process of divergence rather than convergence.

(p. 378) More specifically, while CSR emerged as a concept and discussion back in the 1950s and 1960s, driven by corporate practice and management scholars, BHR only emerged as a systematic debate in the mid- to late 1990s, driven first and foremost by NGO investigations and campaigns as well as by legal scholars (Ramasastry, 2015). Accordingly, the dominant focus of the two discussions has been rather different: while CSR has traditionally focused on voluntary business initiatives and the transformation of busi- 
ness conduct from within, BHR has had a strong emphasis on law-driven approaches, drawing on legal and policy instruments to demand and enforce responsible business conduct from outside (Wettstein, 2016). Against this background, rather than emerging as a subtheme of the CSR field or even as a CSR issue, BHR can be interpreted as a critical response to what has been perceived by some as a stalling or even failing CSR discussion (see, e.g., Banerjee, 2008; Fleming \& Jones, 2013). Digging deeper, we can observe differences between the two approaches at the normative or foundational level and at the institutional level as well as at the operational level (Wettstein, 2016).

\section{Differences at the Normative Level}

CSR is commonly seen as a voluntary responsibility that corporations adopt beyond compliance with laws. It is often perceived as an expression of going above and beyond what is required of businesses. Thus, CSR vocabulary alludes to voluntarism and desirable business conduct rather than to ethical imperatives and duties owed by businesses. As a result, businesses have often perceived CSR to provide ample leeway both in regard to what issues to focus on and by what means to address them (Wettstein, 2012a). However, such voluntarism runs counter to the common understanding of human rights. Human rights, whether interpreted through the lens of morality (Sen, 2004), the law (Shelton, 2014), or distinct cultural practices (Kurasawa, 2014), aim at the protection and promotion of our fundamental dignity as human beings. However, the urgency and fundamental nature of the claims emanating from our unconditional human dignity do not sit well with the perceived voluntarism of conventional interpretations of CSR. Respecting and protecting human rights is not a matter of goodwill or an expression of going above and beyond; it is what John Ruggie called "a baseline expectation" (2008: 17) for all businesses. Thus, equating BHR with CSR comes at a normative cost: conceptually, it risks turning human rights responsibility and indeed an increasingly critical part of realizing human rights as such into mere acts of corporate goodwill, which threatens to undermine the very core of what human rights aim to protect: the unconditional and equal dignity of all human beings. Practically, it encourages corporations to selectively meet human rights standards on their own terms. Politically, it fosters public indifference toward corporate human rights conduct and promotes hands-off public policy, which sees little need to hold companies accountable for their human rights impact.

\section{(p. 379) Differences at the Institutional Level}

As outlined above, CSR is often perceived as the responsibilities that corporations have beyond legal laws and government regulations. This is due to CSR traditionally presupposing a functioning state and a strong institutional framework (Scherer \& Palazzo, 2007). Within such a framework, corporate responsibility is seen as private responsibility, while the public domain is the responsibility of governments alone. As a consequence, CSR can be conceptualized independently of the role and responsibility of governments. $\mathrm{BHR}$, on the other hand, becomes relevant particularly and perhaps predominantly in contexts of dysfunctional or weak state institutions (Karp, 2014), that is, in contexts in which governments fail to meet their public responsibilities. It is against this background

Page 6 of 27

PRINTED FROM OXFORD HANDBOOKS ONLINE (www.oxfordhandbooks.com). (C) Oxford University Press, 2018. All Rights Reserved. Under the terms of the licence agreement, an individual user may print out a PDF of a single chapter of a title in Oxford Handbooks Online for personal use (for details see Privacy Policy and Legal Notice). 


\section{Human Rights, Emerging Markets, and International Business}

that BHR emerges as a discussion of particular relevance not least for the emerging markets context, whereas CSR, at least in its dominant conventional interpretation, may have significant limitations in addressing the challenges emanating from them. In such contexts, corporate human rights responsibility often extends far into the public realm and the separation of private and public domains often breaks down entirely. For better or for worse, in such contexts, corporate human rights responsibilities are closely intertwined with the role and responsibility of governments. Thus, as opposed to CSR, which is perceived as private responsibility beyond the realm of the government's public responsibility, BHR denotes the extension of corporate responsibility into the public sphere. As such, it entails a renegotiation of public responsibility between the government and corporations; we cannot conceptualize corporate human rights responsibility without due consideration of the respective responsibilities of governments (Wettstein, 2016). It is thus not a coincidence that the UNGPs do not merely address business responsibilities like so many other CSR standards but tackle the responsibilities of both corporations and of governments in an integrated way. This being said, the newer discussion on political CSR, which started to emerge in the mid-2000s, has proposed to conceptualize CSR along such lines of weakening states, of global governance gaps, and of a dissolving public-private dichotomy (Scherer \& Palazzo, 2007). As such, political CSR has the potential to serve as a conceptual bridge between the two discussions.

The consequence of this blurring of the lines between public and private in the BHR space, I believe, can be twofold. Where institutions are strong, we can observe that governments take a much more active role as actual players in the BHR space, rather than a passive role in merely shaping the context in which corporations rather selectively meet their social responsibilities. The recent "wave" of national action plans (NAPs) on business and human rights issued by a good two dozen states bears witness to this difference. Where institutions are weak, on the other hand, there is a danger that governments retreat from the human rights space altogether and leave it to the corporations to deal with the respective responsibilities in their stead (Ruggie, 2008). While such processes may occur particularly in notoriously weak and dysfunctional states, emerging markets might occupy various positions on this spectrum between weak and strong institutional (p. 380) settings. As we will see below, while most NAPs have been published by Western, particularly European, countries to date, the second wave of NAPs will include a number of emerging economies as well.

Similar things can be said also about the role of the law in the BHR space (Wettstein, 2016). In traditional CSR, the role also of the law is rather peripheral and indirect. Rather than to actively intervene and enforce CSR, it shapes, defines, and sets the boundaries for the context within which corporations meet their private social responsibilities. At best it may encourage and facilitate CSR by enhancing the conditions for corporations to do so. BHR, on the other hand purports a much more active and interventionist role of the law. The quest for legal accountability, as argued above, is enshrined fundamentally in the identity of the BHR movement. This push for legal accountability is mirrored particularly in intensifying discussions on home-state obligations in regulating and adjudicating the extraterritorial conduct of "their" multinationals as well as in an increasing number of hu-

Page 7 of 27

PRINTED FROM OXFORD HANDBOOKS ONLINE (www.oxfordhandbooks.com). (c) Oxford University Press, 2018. All Rights Reserved. Under the terms of the licence agreement, an individual user may print out a PDF of a single chapter of a title in Oxford Handbooks Online for personal use (for details see Privacy Policy and Legal Notice). 


\section{Human Rights, Emerging Markets, and International Business}

man rights litigation cases, which are brought to domestic courts in a growing number of home states. Against this background, the reopening of treaty negotiations at the UN level only four years after the publication of the non-binding UNGPs, in 2015, seems like an almost logical step on the trajectory of the BHR debate.

\section{Differences at the Operational Level}

There naturally is some overlap between operational CSR measures and initiatives and such in the BHR space. Many of the various CSR initiatives and instruments that companies have in place do address human rights issues directly or indirectly. However, as mentioned above, CSR initiatives and instruments have traditionally addressed a large range of issues and, accordingly, vary substantially in nature and appearance between sectors, industries, and companies. Moreover, many of such initiatives and projects are only loosely connected to the companies' core business and management processes and have often been criticized to serve as mere add-ons to companies' business activities and thus to change little to nothing about the way those companies conduct their business (Ulrich, 2008). Accordingly, organizational policies relating to CSR are often incoherent and conflict across departments and functions and their impact on a company's core business is often piecemeal and unsystematic. This seems to apply both to Western and to emerging market MNCs, as the difference between the two in respect to their CSR approaches are reportedly small (Baskin \& Gordon, 2005).

While initiatives and approaches certainly vary also for BHR, the publication of the UNGPs serves not only as an umbrella for those different initiatives, but established human rights due diligence (HRDD) as an overarching process and instrument to ensure human rights respect across all different sectors and industries. Accordingly, in order to meet their responsibility to respect human rights, companies have to engage in a process of assessing their human rights impact, of taking adequate measures to mitigate or eliminate negative impacts, and of reporting on such measures publicly. (p. 381) While the implementation and operationalization of HRDD must be specific to the respective industry context, the UNGPs provide clear boundaries within which such operationalization ought to take place. Importantly, by definition, HRDD connects directly to the daily business and operations of companies, rather than being disconnected from it. While HRDD should not be seen as a magic potion or silver bullet, it seems that, if carried out with proper care, it has the potential if not to change the culture and value foundation of a company at least to cut through to corporations' core business processes and to provide effective safeguards against violations of human rights within and through them. Nevertheless, some emerging market contexts, in which human rights do not enjoy strong political backing and where human rights discourse and practices are not only neglected but openly suppressed by governments, admittedly pose particular challenges to corporations' willingness to engage with human rights in explicit terms. With the rise of populist movements putting increasing pressure on human rights, companies may become more reluctant to address human rights in their own right rather than through a "CSR filter" also in the West. On the other hand, both of those contexts also offer opportunities for corporate champions to leave a positive mark by supporting human rights movements and defend-

Page 8 of 27

PRINTED FROM OXFORD HANDBOOKS ONLINE (www.oxfordhandbooks.com). (c) Oxford University Press, 2018. All Rights Reserved. Under the terms of the licence agreement, an individual user may print out a PDF of a single chapter of a title in Oxford Handbooks Online for personal use (for details see Privacy Policy and Legal Notice). 
ers (Ineichen, 2018) and by standing up for human rights (Wettstein, 2010; Wettstein \& Baur, 2016)

\section{Institutional Landscape (International Level)}

Early attempts to institutionalize human rights responsibility particularly for multinational corporations can be traced back to the 1970s. Most prominently, the OECD Guidelines for multinational enterprises were established in 1976 and included one paragraph specifically devoted to human rights responsibility. The OECD Guidelines have continuously enhanced their human rights provisions in subsequent iterations. Most recently, in 2011, they included a human rights section, which is closely aligned with the UNGPs. The UN, too, launched an early attempt of a code of conduct for multinationals back in 1977, along with the foundation of a center for transnational corporations. Similar to the OECD Guidelines, the so-called UN Draft Code included a paragraph on human rights as well as a provision on corporations' interaction with authoritarian and racist governments. However, unlike the OECD Guidelines, the UN Draft Code was abandoned in the 1990s and the center was dissolved. Interestingly and relevant for the context of this book, the UN Draft Code was an initiative that was pushed decisively by developing countries and it was aimed at countering the perceived neo-colonialism and exploitation of the South emanating from the global expansion of Western multinationals (Ramasastry, 2013). It was met by the resistance precisely of those Western multinationals and their governments. As we will see shortly, four decades later we are facing a similar constellation in regard to the new treaty negotiations, (p. 382) which are currently under way. While the treaty negotiations were initiated and have since been supported predominantly by emerging and developing economies, Western governments have yet to play a more constructive role in the process.

While these precursors of the current wave of institutionalization were able to plant a seed, the first international initiative on responsible business conduct, which truly put human rights center stage, was the UN Global Compact (Wettstein, 2012b). The UN Global Compact was launched in the year 2000 by then UN Secretary General Kofi Annan and is a voluntary, normative standard consisting of ten principles for responsible business. Principles one and two, respectively, ask signatory organizations to neither violate human rights directly through their business conduct nor contribute indirectly to human rights violations committed by other actors. Some 17 years after its launch, the UN Global Compact counts more than 10,000 signatory organizations and is often seen as the most successful corporate responsibility standard globally. Importantly, the UN Global Compact established human rights responsibility as a key component of responsible business conduct and introduced some of the key terms and vocabulary of the ensuing business and human rights discussion.

Even two years earlier, in 1998, the UN Sub-Commission on Human Rights put in place a working group tasked with drafting what was eventually meant to become a mandatory standard specifically for corporate human rights responsibility. The drafting process, 


\section{Human Rights, Emerging Markets, and International Business}

spearheaded by University of Minnesota law professor David Weissbrodt, lasted five years, producing what is now known as the UN Draft Norms (see Weissbrodt, 2005; Weissbrodt \& Kruger, 2003). The UN Draft Norms faced harsh criticism and opposition, again, by many predominantly Western governments as well as from the private sector. They were eventually shelved by the UN Commission on Human Rights, which argued that it had never tasked the sub-commission with developing such an instrument and thus would not consider adopting it. Nevertheless, the UN Draft Norms were important for two reasons: first, it was the first initiative at the global level that not only put human rights center stage, as the UN Global Compact had, but turned them into its exclusive focus and purpose. While in the UN Global Compact only two of ten principles address human rights, the UN Draft Norms consist of human rights norms exclusively. Second, the heated discussion evolving around the UN Draft Norms and ultimately leading up to their failure showed the urgent need for a systematic discussion on BHR at the international policy level. Thus, it was this discussion that paved the way to the creation of the mandate of a UN special representative for business and human rights (SRSG) in 2005.

It was Harvard professor John Ruggie who was appointed to pursue this new mandate, which was initially limited to a period of two years but eventually extended twice until mid-2011. In 2008, the SRSG published the "Respect, protect and remedy Framework" (Ruggie, 2008) which provided the conceptual foundation for the subsequent UNGPs (Ruggie, 2011), which were published in June 2011. John Ruggie succeeded in getting the BHR unstuck after the UN Draft Norms failure and to turn the UNGPs into a focal point in the debate around which the various stakeholders could rally. Up to this day, the UNGPs remain the main policy instrument and the most important force in driving the implementation (p. 383) of human rights responsibility within companies. Therefore, we will analyze the UNGPs in more detail in the following section.

While the UNGPs remain the most significant policy initiative in the BHR field at the global level, there have been significant other developments since their publication in 2011 . Most important, perhaps, is the above-mentioned successful new attempt by the governments of Ecuador and South Africa to start new negotiations on a binding treaty on BHR at the UN level (see Lopez 2017; Lopez \& Shea, 2016). It is not surprising, perhaps, that the initiative to start such negotiations came from emerging economy governments. Facing much of the world's human rights violations with company involvement while being dependent on those very companies and their foreign direct investment places a dilemma on such governments and often forces them to prioritize economic goals over human rights (Giuliani \& Macchi, 2014). Global rules can help to resolve the dilemma by easing the competitive pressure on emerging economies and thus allowing them to raise standards without paying an unreasonably high economic prize. After Ecuador and South Africa's petition passed the UN Human Rights Council, an open-ended intergovernmental working group was put in place and treaty discussions started in 2015.

Thus, ten years after John Ruggie put an end to the discussions around the UN Draft Norms-what is now referred to as John Ruggie's "Normicide" (Ruggie, 2013: 158)-the pendulum may swing back in the direction of a legally binding instrument. Considering 


\section{Human Rights, Emerging Markets, and International Business}

the ongoing global power shift and the increasing readiness of emerging economies to assert their growing collective influence in the global arena, the trajectory of the current treaty negotiations, while naturally uncertain, may be significantly different from the negotiations of the UN Draft Norms 15 years ago. A similar push for mandatory rules can be observed also at the domestic level in various countries as a result of the UNGPs' implementation process. We will have a look at such developments in more detail in the following section.

\section{The UNGPs in Particular}

As introduced above, the UNGPs were published in June 2011, resulting from a six-year mandate of the SRSG. They are the authoritative policy instrument at the global level today and the "focal point" on which the BHR debate centers.

In a nutshell, the UNGPs rest on three pillars: first, governments' duty to protect human rights from corporate abuse. Second, companies' responsibility to respect human rights. The corporate responsibility to respect human rights is understood as a responsibility of non-violation, that is, a responsibility to violate human rights neither directly through their own conduct nor indirectly by contributing to or being linked with human rights violations committed by third parties, such as suppliers, host governments, or business partners. Third, a joint governmental and business responsibility to improve victims' access to effective remedies. While the first pillar of the UNGPs (p. 384) outlines legally binding duties for governments, which are derived from existing international law, the second pillar is not meant to create new binding norms or rules but ought to be understood as a voluntary business responsibility derived from changing social expectations toward corporations.

Thus, the UNGPs adhere to the tradition of soft-law governance and lack any direct enforcement mechanisms. Rather, the UNGPs count on national governments to put the respective mechanisms toward their effective implementation in place. For doing so, they suggest that governments should use a "smart mix" of measures, both national and international, as well as binding and non-binding (Ruggie, 2011: 8). It is peculiar that the UNGPs hand the task of enforcement exclusively back to national governments after locating the root cause of the BHR predicament, which gave rise to the need for the UNGPs in the first place, precisely in such governance gaps, emanating from governments lacking will or capacity to regulate businesses in the human rights space. In the emerging markets context in particular, the expectations that governments will or can ensure human rights respect through legislative and policy measures in a comprehensive way is illusory, given that their competitiveness often hinges on keeping labor and environmental standards relatively low. Against this background, it is of little surprise that most of the activity that has been catalyzed by the UNGPs at the domestic (as opposed to the global) level so far, can be observed in the Western European context. Some of the most recent developments indeed point in the direction of turning the UNGPs, or parts thereof, into domestic law. 


\section{Human Rights, Emerging Markets, and International Business}

At the policy level, growing number of governments have recently released NAPs on BHR. However, of the 18 published NAPs at the time of writing this chapter, only three are from countries outside Europe (USA, Colombia, Chile), none are from Africa, and none from Asia. Thus, while emerging economies were no early starters in terms of developing NAPs, some of them have recently started to develop them or have launched alternative government-sponsored initiatives. Among them are nations like Kenya, Ghana, Zambia, Tanzania, Uganda, Indonesia, or Malaysia. A total of 27 countries (including a number of advanced economies) have recently started engaging in such processes, indicating that seven years after the publication of the UNGPs, their implementation process is increasingly reaching emerging economies. ${ }^{1}$ Such NAPs outline the basic commitment of national governments to the UNGPs and their prospective strategies in implementing them. While, by and large, those NAPs remain vague and rather noncommittal, they do signal BHR has arrived on governments' agenda and will likely remain there for the foreseeable future. This relates directly to the above insights on institutional differences between CSR and BHR.

At the legislative level, there has been a recent push by lawmakers and grassroots organizations to render human rights due diligence mandatory at domestic levels. This is despite the fact that most of such NAPs are cautious in proposing new legislation in the BHR space. A number of countries have adopted new legislation in the most recent past or are in the process of negotiating such. By and large, such are Western European countries (and in the United States) with strong progressive forces in their governments (e.g., the USA under the Obama Administration) and parliaments (e.g., France) as well (p. 385) as influential civil society sectors (e.g., Switzerland). The aim of such legislation is to regulate the extraterritorial conduct of companies' foreign operations, thus filling the regulatory gaps in the environmental and social realm that such companies may encounter when operating in contexts of institutional voids. Most prominently, France has adopted a new duty of vigilance law, which mandates HRDD according to the UNGPs for large multinationals headquartered in France. In the UK, the UK Modern Slavery Act, which was adopted in 2015, requires UK businesses to report on their efforts-in essence, their HRDD - to eliminate slave and forced labor in their operations and supply chains. A similar law exists in California, i.e., the California Supply Chain Transparency Act. Negotiations for similar legislation are under way also in Australia. Meanwhile, the Netherlands are in the process of adopting legislation that will require companies to conduct HRDD in order to combat child labor in their operations and supply chains. The Dutch law will cover not only Dutch companies but all companies that serve Dutch markets, even if they are headquartered outside the Netherlands. In a similar vein, Section 1502 of the Dodd-Frank Wall Street Reform and Consumer Protection Act establishes mandatory due diligence relating to conflict minerals. Similar regulation has been adopted in 2017 by the EU, mandating supply chain due diligence for importers of conflict minerals. In Switzerland a broad and growing coalition of nearly 100 NGOs and civil society organizations have launched a popular initiative aiming to establish comprehensive mandatory HRDD legislation. The Swiss people will vote on their proposal in 2019. 


\section{Human Rights, Emerging Markets, and International Business}

There has been some controversy around such new laws in regard to whether or not they denote an imposition of legal rules and moral values of "home states" onto the context of "host states" (Kobrin, 2009). Interestingly, it seems that such objections are voiced predominantly by critics in home states rather than in host states. This is noteworthy and perhaps somewhat ironic particularly against the background that, as seen above, most support for similar binding rules at the international level has traditionally come from emerging economies-in the case of the UN Draft Code specifically based on the fear that the unchecked economic activity of multinationals itself denotes a form of Western imperialism.

At the adjudicative level, the past 20 years have heralded a growing number of human rights litigation cases in domestic courts in the home states of multinational companies. Initially, most such cases were brought to US courts based on the Alien Tort Statute, but recent years have seen a diversification in terms of both litigation strategies as well as targeted jurisdictions. This is mainly due to a seminal Supreme Court ruling in 2013 on a lawsuit brought against Shell by the widow of the murdered Ogoni activist Barinem Kiobel. This ruling established a presumption against ATS's extraterritorial application, which raised the bar to bring such cases to US courts. Furthermore, in the most recent Jesner v. Arab Bank case, the Supreme Court denied applicability of ATS to foreign corporations across the board. As a consequence, victims of human rights abuse and their lawyers had to look for other avenues to take cases to domestic home-country courts of multinationals. One way to do so is to base such lawsuits on different legal grounds, such as the above-mentioned California Supply Chain Transparency Act; (p. 386) another way is to bring them to countries other than the USA, such as, for example, the Netherlands, UK, Germany, or Canada. Irrespective of where such lawsuits have been brought to court and on what grounds, most of them were dismissed in the past. Very few of them led to out-of-court settlements and none of them ended in a guilty verdict against a Western parent company (Schrempf-Stirling \& Wettstein, 2017). In one case, Milieudefensie v. Shell, adjudicated in the Netherlands, a Nigerian subsidiary of Shell was found guilty of human rights abuse, while the parent company was acquitted from any wrongdoing. The case has been appealed. Despite the lack of "guilty verdicts" there is a progression toward more rather than fewer such cases and in an increasing number of different countries. In combination with the above legislative innovations, it may be a matter of time until some first cases will succeed and set important precedents.

As these elaborations on UNGPs implementation at the policy, legislative, and adjudicative levels imply, the evolving governance infrastructure in the business and human rights space shows a significant blurring of the traditional categories of hard versus soft law. The domestic enforcement of global soft law and their use as a reference point in domestic court cases leads to a process of hardening of soft law. Having a closer look particularly at such lawsuits we can observe that they tend to fail particularly in the legal domain. However, in most cases they push companies to adopt and commit to soft-law initiatives, to start reporting on their human rights performance, or to implement other measures and safeguards to ensure human rights respect (Schrempf-Stirling \& Wettstein, 2017). Thus, while the lawsuits seem not to lead to the desired "hard" results, they strengthen 
and promote soft measures. We can thus observe an opposite process of a softening of hard law at the same time. It seems that such processes in the space of global governance are of significant relevance particularly to businesses operating at a global scale. Thus, assessing the BHR space based on the traditional dichotomy between hard and soft measures will likely lead to an incomplete understanding of the dynamic interrelation between hard and soft law today and thus fall short on providing good guidance for companies to adequately navigate the increasingly complex business and human rights space.

\section{Key Themes and Open Research Needs in BHR}

There are a number of key research themes and open research questions that derive from the current scholarly discussion on BHR more generally and against the background of this evolving institutional infrastructure more specifically. I will attempt to outline just a few of them, structuring them along global, domestic, and operational levels. More specific, emerging market-oriented research themes and gaps will be addressed in the subsequent section.

\section{(p. 387) Global Level}

Not surprisingly, the treaty negotiations in the UN Human Rights Council has been a key research focus of BHR scholars in recent times. Such research has addressed normative arguments surrounding the treaty discussions (Bilchitz, 2016) as well as questions relating to form and scope of a potential treaty (DeSchutter, 2016) and to the broader context in which it ought to be embedded (Deva \& Bilchitz, 2017). There has been much discussion about the danger that such treaty negotiations may stall and delay the implementation process of the UNGPs (Ruggie 2014). Arguments in this regard tend to adhere to the common dichotomy between mandatory and voluntary approaches as two distinct and potentially opposing governance mechanisms. However, looking at these instruments from the vantage point of a complex interplay between binding and non-binding approaches as outlined above may open new perspectives on their potential complementarities and synergies in promoting human rights respect of companies. More generally, understanding the blurring between soft and hard law in different dimensions is a key research area that needs to be explored, not least to understand better what effective business and human rights governance can and ought to look like.

A more specific question related to the changing governance structure at the global level is how the established BHR framework and the UNGPs in particular relate to and ought to engage with the Sustainable Development Goals (SDGs) framework (see, e.g., Gneiting, Bloch Veiberg, \& Mehra, 2017). There is a danger, for example, that shifting the focus to the SDGs and thus to the positive potential of businesses to contribute to their realization may divert our attention from preventing businesses to do harm and making sure they do not violate human rights in the first place. Furthermore, there is a possibility that the broad range of issues addressed by SDGs will lead to a selective approach by businesses, cherry-picking certain goals, which can be served effortlessly while dropping others that 


\section{Human Rights, Emerging Markets, and International Business}

would require substantial organizational investments and changes. Such approaches are readily commensurable with current CSR thinking and thus there is a danger that companies will latch on to the SDGs agenda not in addition or as a complement to a commitment to human rights but as a replacement of it. This possibility is supported by recent research showing that companies tend to avoid human rights language in their communication, because of its potential political sensitivity (Obara, 2017). From this perspective, the vocabulary of the SDGs may be seen as a welcome alternative by many companies. As a consequence, BHR advocates increasingly call for embedding human rights and the business responsibility to respect them at the very core of the SDGs (UN Working Group on BHR, 2017). However, little scholarly work has been done so far that analyzes in depth the relation between the SDGs and the UNGPs and on the implications of the SDGs for the implementation of the business and human rights agenda. There seems to be a more conflictual relation between the SDGs and recent developments in the legislative arena at both the domestic and the international level. In current political discourses on such legislation, there seems to be a tendency to put the SDGs in direct opposition with potential binding BHR legislation (p. 388) in current policy discussions. Opponents of such legislation in particular perceive the SDGs as an alternative and indeed opposing approach to binding BHR legislation and regulation, whereas proponents tend to dismiss them based on their non-binding character. Infused with ideologically hardened positions, such polarized policy debates tend to obscure, rather than advance, a deeper understanding of the interdependence and interplay of such different governance initiatives. As a result, there is a need for systematic scholarly engagement with them.

\section{State Level}

There are some underemphasized areas in the UNGPs which are currently emerging as key research themes at the state level. Among them are the state's role in providing access to justice and remedy to victims of human rights violations committed by home-state companies abroad. Access to remedy is one of the three central pillars in the UNGPs, but it has been much neglected in current implementation efforts. While most attention has been given to the first two pillars, the issue of remediation has been neglected both in the NAPs of governments as well as in company policies on human rights respect. Accordingly, there is a need for more and better research on effective remedy mechanisms, both judicial and non-judicial, and particularly on the interrelation between them. There is an evolving discussion, for example, on the use of the so-called National Contact Points of the OECD Guidelines for business and human rights issues (Nieuwenkamp 2014; Ochoa Sanchez 2015). However, their relation to and potential complementarity with evolving legislation in the business and human rights field remains underexplored. More generally, keeping in mind the complex interplay between voluntary and mandatory measures as well as the transformation of their respective mode of operation when combined, raises the question about the nature and shape of what John Ruggie called a "smart mix" of measures to promote human rights respect of businesses at the domestic level. 


\section{Human Rights, Emerging Markets, and International Business}

A directly related, normative discussion that has received increasing attention as of late refers to potential extraterritorial obligations of home states in preventing and possibly adjudicating human rights violations committed or contributed to by "their" companies abroad (Simons \& Macklin, 2014). The area of extraterritorial obligations of states has been addressed only superficially in the UNGPs; the SRSG avoided taking a position on this thorny issue in the UNGPs for pragmatic reasons: taking a forceful stance on extraterritorial obligations would likely have irritated the business community whose support was deemed critical for the successful adoption of the UNGPs by the Human Rights Council. Apart from the need to understand better both such obligations in and of themselves as well as their adequate implementation through home-state legislation, regulation, and adjudication, this discussion raises related questions, e.g., on the potential economic impact of such measures on home states and host states, on the legitimacy of extraterritorial measures in relation to host-state sovereignty, or more generally on their impact on institutional development, e.g., of the judiciary, in host states. (p. 389) Such questions seem of particular relevance for emerging market contexts and will therefore be addressed in more detail in the following section.

\section{Operational Level}

There has been a surge in empirical, management-oriented research on BHR as of late. Such research has looked at the sense-making and framing processes at play, when corporations grapple with the implementation of human rights respect (Goethals, 2016; Obara, 2017), at the role specifically of CSR in such sense-making processes (Obara \& Peattie, forthcoming), on the implementation of HRDD (McCorquodale, Smit, Neely, \& Brooks, 2017) as well as on the shortcoming of such HRDD processes conceptually (Fasterling, 2017) and their limitations in addressing the structural root causes of many human rights violations (Tuta, 2017; Wettstein, 2015). However, there is still a lack of information about the general uptake and impact of the UNGPs among companies, about the way they are implemented and embedded within the core business processes and how they are or will be affecting the structural and cultural dimensions of corporations and the business models on which they are built. A further area in which sound empirical research is needed is in regard to the economic impact of both human rights respect and human rights abuse, that is, on the so-called business case for human rights respect. While much of companies' commitment to human rights and social responsibility more generally is driven by the belief that it will pay off economically, evidence of such a correlation is mixed at best (see, e.g., Orlitzky, Schmidt, \& Rynes, 2003; Rost \& Ehrmann, 2017). Thus, there is much value to new and innovative research in this area conceptually as well as practically. Such research should focus not only on the positive potential of human rights respect, but also on the limits of business case thinking. It should thus include contexts and circumstances in which human rights abuse may go unpunished by the market or even pay off for companies, that is, it should assess critically also the potential business case for human rights abuse. 


\section{BHR in Emerging Market Contexts}

After outlining some key research themes and questions of the BHR debate more generally, we will now reflect on their implications in the more specific context of emerging economies and emerging economies research. Fast economic growth paired with high inequality levels and an often underdeveloped human rights infrastructure render the context of emerging economies particularly relevant and interesting from a business and human rights perspective.

While developed economies are not immune to human rights violations committed or contributed to by companies, a large percentage of such violations on record arguably occur in less developed and emerging economies (Ruggie 2013: 24). However, many of (p. 390) them are connected to the operations of Western multinationals and their global value chains. Certain industries which are prone to such occurrences are characteristic for and in many cases dominant in emerging economies, such as the garment and apparel sector, extractive industries, fishery or construction sectors, among others (Ruggie 2013: 25). But also knowledge-driven sectors such as the information technology (IT) and telecommunication sector are becoming of increasing importance in emerging markets and can often be connected to specific kinds of human rights violations, such as the suppression of freedom of speech or arbitrary detention and imprisonment for political advocacy. Accordingly, the business and human rights agenda poses particular challenges both for "Western" companies expanding their value chains and doing business in emerging economies as well as for emerging economy multinationals keen to expand into "Western" markets, in which they have to cope with a tighter regulatory framework as well as a more demanding consumer, investor, and citizen base in regard to social, environmental, and human rights expectations. These are the two main contexts from which an emerging market-related research agenda in BHR emerges. The following paragraphs will structure this twofold research agenda again into implications at the global, the state, and the company level.

\section{Implications and Research Themes at the Global Level}

There are two emerging trends and developments impacting on emerging economies that seem of particular relevance from a global BHR perspective. First, there is the looming shift from (South)east Asia to Africa as the future "factory of the world." Not only will this have an effect on the work situation in the impacted countries both in Asia and in Africa, but the shift is driven not least by the increasing global investment and sourcing activities of emerging economies themselves. China in particular is heavily driving this shift toward Africa. Second, automation and artificial intelligence (AI) will likely impact emerging markets in profound ways, as it may replace much of traditional factory labor and drive production from emerging markets back into developed economies. While this may reduce the risk of Western multinationals to be linked to and implicated with gross labor rights abuses in emerging economies, it may have devastating impacts on the livelihood of affected workers and on broader socioeconomic development in those countries more generally. Thus, the digital revolution will bring with it its own structural human rights 


\section{Human Rights, Emerging Markets, and International Business}

challenges, which will be of existential importance for emerging economies. Much will depend on how companies will manage the large-scale human rights implications deriving from their full transition into the "digital age."

\section{Implications and Research Themes at the State Level}

As indicated above, one of the central evolving discussions within the business and human rights field deals with the obligations of home states to regulate and possibly (p. 391) adjudicate human rights violations committed by multinationals in host states. There is much discussion about the implications of such measures on home states themselves, particular in regard to multinationals threatening to relocate their headquarters to countries with looser regulative frameworks. With emerging market multinationals becoming more competitive in global markets, Western multinationals may increasingly perceive themselves to be put in competitive disadvantage by stricter and more extensive home-state regulations. As a result, they may advocate for loosening regulatory frameworks aimed at the protection of human rights in their home states.

However, perhaps of more relevance are the possible implications of such regulation on the host states, particularly in emerging economy contexts. Critics of such home-state regulation of transnational business activities in particular have warned that there may be adverse or even counterproductive side effects of such measures. More specifically, they fear that Western multinationals would pull out of high-risk markets altogether if subjected to costly due diligence requirements and litigation risk, which would end up hurting local populations, rather than helping them. More independent, scholarly research on such unintended consequences, but also on the potential positive impact of such regulation on the rights of affected communities and stakeholders, is needed to provide a more holistic picture of how such measures impact emerging economies. As an example, looking at some of the available assessments of Section 1502 of the Dodd-Frank Act provides an ambiguous picture indeed. While some laud the provision for reducing the presence of armed groups controlling mining areas and dramatically increasing the export of conflict free minerals from eastern Congo (Dranginis, 2016), others assert that it drives countless artisanal miners out of business and point to endemic difficulties in regard to the law's enforcement on the ground (Wolfe, 2015). Thus, there is a need to take a differentiated look at such regulatory tools, and to research and anticipate more precisely the intended and unintended impacts and to design them as "precision tools" (Ruggie, 2013: xlvi) with the potential to amplify the positive impacts and avoid the negative ones.

Another key research theme at the intersection of BHR and emerging economy scholarship deals with the institutional impact of Western multinationals in emerging economies (see, e.g., Santoro, 2000, 2009). It may be of particular relevance to explore if and how such multinationals do or do not help to raise the bar in institutional human rights protection in emerging markets by, e.g., modeling responsible business conduct and pushing for progressive economic and political reform (positive), or by exploiting regulatory gaps and pressuring governments to ease regulation aimed at the environmental and social protec- 


\section{Human Rights, Emerging Markets, and International Business}

tion (negative). There may be similar value to tracking the responses of developed economies to the increasing presence of emerging economies multinationals in the global economy. More specifically, will the push of emerging economy multinationals into the global markets increase Western governments' caution to regulate their own companies due to fears of decreasing their competitiveness? Such findings would support the idea that global structural problems require global solutions, as proposed, e.g., by a binding international treaty on BHR. As pointed out (p. 392) above, such binding solutions at the international level tend to be supported first of all by the governments of emerging economies.

\section{Implications and Research Themes at the Operational Level}

As emerging economy multinationals are pushing into global markets, the question arises not only if and how Western governments are prepared to receive them, but also how those companies themselves are prepared to meet the potentially higher demands and expectations in established markets abroad. Human rights have been a rather marginal focus within research on emerging market multinationals (Giuliani, Santangelo, \& Wettstein, 2016).

Human rights respect may be an area in which liabilities of foreignness (see, e.g., Kostova $\&$ Zaheer, 1999) may be of particular relevance for emerging market multinationals (Giuliani et al., 2016). That is, emerging market multinationals originating from contexts in which human rights protections may be low, freedom of speech and information may be systematically suppressed, and oppression of minorities in terms of race or political, sexual, and religious orientation may be rampant, face an uphill battle for legitimacy when operating in markets where human rights protection is more advanced and where expectations of key stakeholder are higher. Such emerging market multinationals may struggle to bridge the institutional distance between home and host markets and to achieve sufficient legitimacy in foreign economies. Nevertheless, the drivers of change particularly in regard to responsible business conduct and respective emerging market institutional frameworks and policies may be changing. Commonly, the focus has been on Western multinationals doing business in emerging markets and their impact through positive spillovers (Giuliani \& Macchi, 2014) such as knowledge and technology transfer and their role as a driver of socioeconomic development more generally. However, we may need to shift some of this attention from inward to outward foreign direct investment (FDI) and assess how the growing pressure on emerging market multinationals to adopt responsible business practices (see, e.g., Marano, Tashman, \& Kostova, 2017) including human rights policies and due diligence processes drives institutional and organizational changes also at home. Marano et al. (2017), for example, showed that multinationals engage in more intensive CSR reporting if they come from countries with pervasive institutional voids. They do so as a legitimation strategy in order to mitigate the liabilities of origin. In a similar vein, Fiaschi, Giuliani, \& Macchi (2012; see also Giuliani \& Macchi, 2014) argue that for the same reason multinationals from the BRIC countries are more proactive in undertaking CSR initiatives and managing human rights than Western MNCs. On the other hand, such processes of adaptation under pressure may be particularly susceptible to dis- 


\section{Human Rights, Emerging Markets, and International Business}

tortions based on decoupling and greenwashing (Bansal \& Kistruck, 2006; Meyer \& Rowan, 1977). Giuliani and Macchi (2014) point to inconclusive evidence (p. 393) overall and thus to a need for further comparative research on these issues. The same goes for the conduct of emerging market multinationals when they expand into other developing and emerging economies, rather than into advanced markets. Due to weaker legitimation pressure particularly in contexts of weak protections of free speech and an independent press, as Fiaschi, Giuliani, and Nieri (2017) allege, emerging market multinationals tend to be more, rather than less, prone to irresponsible conduct then their Western peers.

Western multinationals may find it challenging to navigate institutional voids in emerging economies particularly when coping with government requests that run counter their own human rights policies and/or the expectations of key stakeholders in their home markets. For example, Internet companies may be faced with requests of Internet shutdowns or to provide sensitive data of their customers to emerging market governments. They may have to tolerate discriminatory policies against minority employees or even be asked to actively contribute to such discrimination through their workplace policies. Emerging economy contexts may be of particular relevance in regard to such dilemmas since, increasingly, companies are faced not with weak and dysfunctional states but with growing governmental power that diminishes the companies' room to maneuver and to resist problematic government requests and policies. Still, there may be opportunities for progressive multinationals to work toward progress as "institutional entrepreneurs" (Garud, Hardy, \& Maguire, 2007) or even use their leverage to push for political reform and the strengthening of human rights protections in such contexts (Wettstein, 2009; Wood, 2012). There is much insight to be gained still in regard to how companies navigate the fine line between imposing their own values and asking for much-needed transformations and in regard to a plethora of other open questions that relate to non-market strategies and human rights conduct of Western multinationals operating in emerging economies. Generally, the relation between Western multinationals and the human rights situation in emerging economies is a complex one with their positive or negative impacts depending on a variety of different variables (Giuliani \& Macchi, 2014), which are in need of further exploration.

\section{Conclusion}

This chapter has introduced BHR as a young but fast-evolving debate and field at the heart of the wider discussion on corporate responsibility. It is a discussion that has emerged not least as a critical response to current approaches to CSR, which have been criticized for their non-committal nature and their general lack of impact. The relation of BHR to the theme of this volume goes two ways. On the one hand, the evolving BHR discussion will likely impact the trajectory of emerging markets in profound ways. The UNGPs in particular have created unprecedented momentum both in the practical and the policy arena. Many governments have published or are in the process of developing NAPs on BHR, signaling a basic commitment to the concern (p. 394) and outlining some (often modest) measures to address it in the future. Businesses have started to implement human 
rights policies and due diligence measures to assess and address their human rights impacts. Civil society is increasingly using the UNGPs to push for increased accountability among companies for their human rights conduct. This development, while still predominantly occurring in OECD countries, is shaping the context in which emerging economy multinationals enter global markets today and it inevitably affects emerging economies more generally, which are not only competing for foreign direct investment but increasingly claiming a share of the global markets themselves.

On the other hand, the rise of emerging economies, the increasing relevance of emerging market multinationals in global markets, and the rising power and assertion of emerging market governments will influence the trajectory also of the BHR debate. The successful initiation of new treaty negotiations in the UN Human Rights Council is an example of the new, more influential role such countries are able to play in international politics. Similarly, the presence of Chinese multinationals in Africa and increasingly elsewhere raises new challenges and opportunities for BHR.

All of this calls for a closer integration of scholarship on BHR with scholarship on IB and emerging markets. While BHR has put little emphasis on the specificity of emerging markets and emerging market multinationals, scholarship on emerging markets has largely ignored human rights in their research so far. A closer integration of the two fields promises a host of new and intriguing research perspectives with a potential to advance both fields in significant ways.

\section{References}

Arnold, D. G. 2016. Corporations and human rights obligations. Business and Human Rights Journal, 1(2): 255-275.

Arnold, D. G. 2003. Moral reasoning, human rights, and global labor practices. In L. P. Hartman, D. G. Amold, \& R. E. Wokutch (Eds), Rising above sweatshops: Innovative approaches to global labor challenges: 77-99. Westport, CT: Praeger.

Arnold, D. G. 2010. Transnational corporations and the duty to respect basic human rights. Business Ethics Quarterly, 20(3): 371-399.

Banerjee, S. B. 2008. Corporate social responsibility: The good, the bad and the ugly. Critical Sociology, 43(1): 51-79.

Bansal, P., \& Kistruck, G. 2006. Seeing is (not) believing: Managing the impressions of the firm's commitment to the natural environment. Journal of Business Ethics, 67(2): 165180.

(p. 395) Baskin, J., \& Gordon, K. 2005. Corporate responsibility practices of emerging market companies. OECD Working Papers on International Investment, 2005(03). Paris: OECD Publishing. http://dx.doi.org/10.1787/713775068163. 
Bilchitz, D. 2013. A chasm between "is" and "ought"? A critique of the normative foundations of the SRSG's Framework and the Guiding Principles. In S. Deva \& D. Bilchitz (Eds.), Human rights obligations of business: Beyond the corporate responsibility to respect?: 107-137. Cambridge: Cambridge University Press.

Bilchitz, D. 2016. The necessity for a business and human rights treaty. Business and Human Rights Journal, 1(2): 203-227.

Bowen, H. R. 1953. The social responsibilities of the businessman. New York: Harper and Row.

Brenkert, G. G. 2016. Business ethics and human rights: An overview. Business and Human Rights Journal, 1(2): 277-306.

Chandler, G. 2003. The evolution of the business and human rights debate. In R. Sullivan (Ed.), Business and human rights: Dilemmas and solutions: 22-32. Sheffield, UK: Greenleaf Publishing.

Davis, K. 1960. Can business afford to ignore corporate social responsibilities? California Management Review, 2: 70-76.

De Schutter, O. 2016. Towards a new treaty on business and human rights. Business and Human Rights Journal, 1(1): 41-67.

Deva, S., \& Bilchitz, D. (Eds.). 2017. Building a treaty on business and human rights. Cambridge: Cambridge University Press.

Donaldson, T. 1982. Corporations and morality. Englewood Cliffs, NJ: Prentice Hall.

Dranginis, H. 2016. Point of origin: Status report on the impact of Dodd Frank 1502 in Congo. The Enough Project. https://enoughproject.org/files/

DRC_PointofOrigin_022016.pdf.

Fasterling, B. 2017. Human rights due diligence as risk management: Social risk versus human rights risk. Business and Human Rights Journal, 2(2): 225-247.

Fiaschi, D., Giuliani, E., \& Macchi C. 2012. Corporate social responsibility and human rights abuses: A comparison of the strategies adopted by advanced country and BRIC multinationals. Notizie di Politeia, 28(106): 34-54.

Fiaschi, A., Giuliani, E., \& Nieri, F. 2017. Overcoming the liability of origin by doing no harm: Emerging country firms' social irresponsibility as they go global. Journal of World Business, 52(4): 546-563.

Fleming, P., \& Jones, M. T. 2013. The end of corporate social responsibility. Los Angeles: Sage Publications.

Frederick, W. C. 1960. The growing concern over business responsibility. California Management Review, 2(4): 54-61. 


\section{Human Rights, Emerging Markets, and International Business}

Frey, B. A. 1997. The legal and ethical responsibilities of transnational corporations in the protection of international human rights. Minnesota Journal of Global Trade, 6: 153-188.

Garud, R., Hardy, C. \& Maguire, S. 2007. Institutional entrepreneurship as embedded agency: An introduction to the Special Issue. Organization Studies, 28(7): 957-969.

Giuliani, E., \& Macchi, C. 2014. Multinationals corporations' economic and human rights impacts on developing countries: A review and research agenda. Cambridge Journal of Economics, 38: 479-517.

Giuliani, E., Santangelo, G., \& Wettstein, F. 2016. Human rights and international business research: A call for studying emerging market multinationals. Management and Organization Review, 12(3): 231-237.

(p. 396) Gneiting, U., Bloch Veiberg, C., \& Mehra, A. 2017. Why the business and human rights community needs to engage with the SDGs. Cambridge Core Blog: November 23. http://blog.journals.cambridge.org/2017/11/23/why-the-business-and-humanrights-community-needs-to-engage-with-the-sdgs/.

Goethals, S. 2016. From business and human rights to human rights in business. Unpublished PhD dissertation. Oxford Brookes University, Oxford.

Hsieh, N. 2017. Business responsibilities for human rights. Business and Human Rights Journal, 2(2): 297-309.

Hsieh, N. 2015. Should business have human rights obligations? Journal of Human Rights, 14(2): 218-236.

Human Rights Watch. 1999a. The Enron Corporation: Corporate complicity in human rights violations. New York: Human Rights Watch.

Human Rights Watch. 1999b. The price of oil: Corporate responsibility and human rights violations in Nigeria's oil producing communities. New York: Human Rights Watch.

Hume, D. 1985 [1740]. A treatise of human nature. London: Penguin Books.

Ineichen, M. 2018. Protecting human rights defenders: A critical step towards a more holistic implementation of the UNGPs. Business and Human Rights Journal, 3(1): 97-104.

Karp, D. J. 2014. Responsibility for human rights: Transnational corporations in imperfect states. Cambridge: Cambridge University Press.

Kobrin, S. J. 2009. Private political authority and public responsibility: Transnational politics, transnational firms and human rights. Business Ethics Quarterly, 19(3): 349-374.

Kostova, T., \& Zaheer, S. 1999. Organizational legitimacy under conditions of complexity: The case of the multinational enterprise. Academy of Management Review, 24(1): 64-81. 


\section{Human Rights, Emerging Markets, and International Business}

Kurasawa, F. 2014. Human rights as cultural practices. In T. Cushman (Ed.), Handbook of human rights: 155-163. London/New York: Routledge.

Lopez, C. 2017. Struggling to take off? The second session of intergovernmental negotiations on a treaty on business and human rights. Business and Human Rights Journal, 2(2): 365-370.

Lopez, C., \& Shea, B. 2016. Negotiating a treaty on business and human rights: A review of the first intergovernmental session. Business and Human Rights Journal, 1(1): 111116.

Marano, V., Tashman, P., \& Kostova, T. 2017. Escaping the iron cage: Liabilities of origin and CSR reporting of emerging market multinational enterprises. Journal of International Business Studies, 48(3): 386-408.

McCorquodale, R., Smit, L., Neely, S., \& Brooks, R. 2017. Human rights due diligence in law and practice: Good practices and challenges for business enterprises. Business and Human Rights Journal, 2(2): 195-224.

Meyer, J. W., \& Rowan, B. 1977. Institutionalized organizations: Formal structure as myth and ceremony. American Journal of Sociology, 83: 340-363.

Muchlinski, P. 2001. Human rights and multinationals: Is there a problem? International Affairs, 77(1): 31-47.

Nieuwenkamp, R. 2014. OECD's human rights grievance mechanism as a competitive advantage. London: Institute for Human Rights and Business. https://www.ihrb.org/other/ governments-role/oecds-human-rights-grievance-mechanism-as-a-competitiveadvantage.

Obara, L. J. 2017. "What does this mean?": How UK companies make sense of human rights. Business and Human Rights Journal, 2(2): 249-273.

Obara, L. J., \& Peattie, K. forthcoming. Bridging the great divide? Making sense of the human rights-CSR relationship in UK multinational companies. Journal of World Business.

(p. 397) Ochoa Sanchez, J. C. 2015. The roles and powers of the OECD national contact points regarding complaints on an alleged breach of the OECD guidelines for multinational enterprises by a transnational corporation. Nordic Journal of International Law, 84(1): 89-126.

Orlitzky, M., Schmidt, F. L., \& Rynes, S. L. 2003. Corporate social and financial performance: A meta-analysis. Organization Studies, 24(3): 403-441.

Ramasastry, A. 2013. Closing the governance gap in the business and human rights arena: Lessons from the anti-corruption movement. In S. Deva \& D. Bilichitz (Ed.), Human 
rights obligations of business: Beyond the corporate responsibility to respect?: 162-189. Cambridge: Cambridge University Press.

Ramasastry, A. 2015. Corporate social responsibility versus business and human rights: bridging the gap between responsibility and accountability. Journal of Human Rights, 14(2): 237-259.

Rost, K., \& Ehrmann, T. 2017. Reporting biases in empirical management research: The example of win-win corporate social responsibility. Business \& Society, 56(6): 840-888.

Ruggie, J. G. 2011. Guiding principles on business and human rights: Implementing the United Nations "Protect, Respect and Remedy" framework. A/HRC/17/31. http:// www.ohchr.org/Documents/Issues/Business/A-HRC-17-31_AEV.pdf.

Ruggie, J. G. 2013. Just business: Multinational corporations and human rights. New York/ London: W. W. Norton \& Co.

Ruggie, J. G. 2008. Protect, Respect and Remedy. A framework for business and human rights. A/HRC/8/5. www.reports-and-materials.org/sites/default/files/reports-andmaterials/Ruggie-report-7-Apr-2008.pdf.

Ruggie, J. G. 2014. Quo vadis? Unsolicited advice to business and human rights treaty sponsors. London: Institute for Human Rights and Business. https://www.ihrb.org/other/treaty-on-business-human-rights/quo-vadis-unsolicited-advice-to-businessand-human-rights-treaty-sponsors.

Santoro, M. A. 2009. China 2020. How Western business can-and should-influence social and political change in the coming decade. Ithaca, NY: Cornell University Press.

Santoro, M. A. 2000. Profits and principles. Global capitalism and human rights in China. Ithaca, NY: Cornell University Press.

Scheinin, M. 2012. International organizations and transnational corporations at a world court of human rights. Global Policy, 3(4): 488-491.

Scherer, A. G., \& Palazzo, G. 2007. Toward a political conception of corporate responsibility: Business and society seen from a Habermasian perspective. Academy of Management Review, 32(4): 1096-1120.

Schrempf-Stirling, J., \& Wettstein, F. 2017. Beyond guilty verdicts: Human rights litigation and its impact on corporations' human rights policies. Journal of Business Ethics, 145: 545-562.

Sen, A. 2004. Elements of a theory of human rights. Philosophy and Public Affairs, 32(4): 315-356.

Shelton, D. L. 2014. Advanced introduction to international human rights law. Cheltenham, UK/Northampton, MA: Edward Elgar. 
Simons, P., \& Macklin, A. 2014. The governance gap. Extractive industries, human rights, and the home state advantage. London/New York: Routledge.

Stiglitz, J. E. 2003. The roaring nineties. A New history of the world's most prosperous decade. New York/London: W. W. Norton \& Co.

Tuta, I. 2017. Created and lost in translation: The corporate management of human rights. Unpublished PhD dissertation. Graduate Institute Geneva.

(p. 398) Ulrich, P. 2008. Integrative economic ethics. Foundations of a civilized market economy. Cambridge: Cambridge University Press.

UN Working Group on Business and Human Rights. 2017. The business and human rights dimension of sustainable development: Embedding "Protect, Respect and Remedy" in SDGs implementation. Geneva: United Nations Human Rights, Office of the High Commissioner. http://www.ohchr.org/Documents/Issues/Business/Session 18/ InfoNoteWGBHR_SDGRecommendations.pdf.

Votaw, D. 1961. The politics of a changing corporate society. California Management Review, 3(3): 105-118.

Weissbrodt, D. 2005. Corporate human rights responsibilities. Zeitschrift für Wirtschaftsund Unternehmensethik, 6(3): 279-297.

Weissbrodt, D., \& Kruger, M. 2003. Norms on the responsibilities of transnational corporations and other business enterprises with regard to human rights. American Journal of International Law, 97: 901-922.

Werhane, P. H. 2016. Corporate moral agency and the responsibility to respect human rights in the UN Guiding Principles: Do corporations have moral rights? Business and $\mathrm{Hu}$ man Rights Journal, 1(1): 5-20.

Wettstein, F. 2012a. CSR and the debate on business and human rights: Bridging the great divide. Business Ethics Quarterly, 22(4): 739-770.

Wettstein, F. 2016. From side show to main act: Can business and human rights save corporate responsibility? In D. Baumann-Pauly \& J. Nolan (Eds.), Business and human rights: From principles to practice: 78-87. London/New York: Routledge.

Wettstein, F. 2012b. Human rights as ethical imperatives for business: The UN Global Compact's human rights principles. In J. Lawrence \& P. W. Beamish (Eds.), Globally responsible leadership: Managing according to the UN Global Compact: 73-88. Thousand Oaks, CA: Sage Publications.

Wettstein, F. 2009. Multinational corporations and global justice. Human rights obligations of a quasi-governmental institution. Stanford, CA: Stanford University Press. 
Wettstein, F. 2015. Normativity, ethics and the UN Guiding Principles on business and human rights: A critical assessment. Journal of Human Rights, 14(2): 162-182.

Wettstein, F. 2010. The duty to protect: Corporate complicity, political responsibility, and human rights advocacy. Journal of Business Ethics, 96(1): 33-47.

Wettstein, F., \& Baur, D. 2016. Why should we care about marriage equality?-Political advocacy as a part of corporate responsibility. Journal of Business Ethics, 138(2): 199213.

White, J. 2004. Globalization, divestment and human rights in Burma. Journal of Corporate Citizenship, 14: 47-65.

Wolfe, L. 2015. How Dodd Frank is failing Congo. Foreign policy. http:// foreignpolicy.com/2015/02/02/how-dodd-frank-is-failing-congo-mining-conflictminerals/.

Wood, S. 2012. The case for leverage-based corporate human rights responsibility. Business Ethics Quarterly, 22(1): 63-98.

\section{Notes:}

(1.) For a comprehensive and up-to-date overview see the toolkit on NAPs developed by the Danish Institute for Human Rights in collaboration with the International Corporate Accountability Roundtable (ICAR): https://globalnaps.org/.

\section{Florian Wettstein}

Florian Wettstein, University of St.Gallen 